\title{
Microwave-Assisted Solvent Extraction and Analysis of Shikimic Acid From Plant Tissues ${ }^{1}$
}

\author{
Extração por Solvente Assistida por Micro-Ondas e Análise do Ácido Chiquímico dos Tecidos de \\ Plantas
}

\author{
MATALLO, M.B. ${ }^{2}$, ALMEIDA, S.D.B. ${ }^{2}$, CERDEIRA, A.L. ${ }^{3}$, FRANCO, D.A. ${ }^{2}$, BLANCO, F.M.G. ${ }^{2}$, \\ MENEZES, P.T.C. ${ }^{2}$, LUCHINI, L.C. ${ }^{4}$, MOURA, M.A.M. ${ }^{2}$ and DUKE, S.O. ${ }^{5}$
}

\begin{abstract}
A better method for determination of shikimate in plant tissues is needed to monitor exposure of plants to the herbicide glyphosate [ $N$-(phosphonomethyl)glycine] and to screen the plant kingdom for high levels of this valuable phytochemical precursor to the pharmaceutical oseltamivir. A simple, rapid, and efficient method using microwave-assisted extraction (MWAE) with water as the extraction solvent was developed for the determination of shikimic acid in plant tissues. High performance liquid chromatography was used for the separation of shikimic acid, and chromatographic data were acquired using photodiode array detection. This MWAE technique was successful in recovering shikimic acid from a series of fortified plant tissues at more than $90 \%$ efficiency with an interference-free chromatogram. This allowed the use of lower amounts of reagents and organic solvents, reducing the use of toxic and/or hazardous chemicals, as compared to currently used methodologies. The method was used to determine the level of endogenous shikimic acid in several species of Brachiaria and sugarcane (Saccharum officinarum) and on $B$. decumbens and soybean (Glycine $\max$ ) after treatment with glyphosate. The method was sensitive, rapid and reliable in all cases.
\end{abstract}

Keywords: glyphosate, green chemistry, herbicide, HPLC.

RESUMO - Um método melhor para a determinação do chiquimato em tecidos de plantas é necessário para monitorar a exposição destas ao herbicida glyphosate $N$-(fosfonometil)glicina] e selecionar o gênero da planta para altos niveis desse valioso precursor fitoquímico ao fármaco oseltamivir. Um método simples, rápido e eficiente, que usa a extração assistida por micro-ondas (MWAE) com água como solvente de extração, foi desenvolvido para a determinação do ácido chiquímico em tecidos de plantas. Foi empregada cromatografia liquida de alto desempenho para a separação do ácido chiquímico, e os dados cromatográficos foram obtidos utilizando arranjo de fotodiodo. Essa técnica de MWAE obteve sucesso na recuperação do ácido chiquimico de uma série de tecidos de planta fortificados, com mais de $90 \%$ de eficiência e um cromatograma livre de interferências. Isso permitiu a utilização de menores quantidades de reagentes e de solventes orgânicos, reduzindo o uso de produtos químicos tóxicos e/ ou perigosos, em comparação às metodologias atualmente empregadas. O método foi usado para determinar o nivel de ácido chiquímico endógeno em diversas espécies de Brachiaria e de cana-de-açúcar (Saccharum officinarum), em B. decumbens e na soja (Glycine max) após o tratamento com glyphosate. O método foi sensivel, rápido e confiável em todos os casos.

Palavras-chave: glyphosate, química verde, herbicida, HPLC.

1 Recebido para publicação em 5.9.2008 e na forma revisada em 11.12.2009.

2 Weed Science Laboratory, Biological Institute, IB, Rodovia Heitor Penteado Km 3,5, 13001-970 Campinas-SP, Brazil, <matallo@biologico.sp.gov.br>; ${ }^{3}$ Embrapa Environment, Brazilian Department of Agriculture, Agricultural Research Service, Caixa Postal 69, 13820-000 Jaguariúna-SP, Brazil; ${ }^{4}$ Agrochemicals Ecotoxicology Laboratory, Biological Institute, IB, Av. Conselheiro Rodriques Alves 1252, 04014-000 São Paulo-SP, Brazil; ${ }^{5}$ Natural Products Utilization Research Unit, USDA, ARS, P. O. Box 8048, University, MS 38677, USA. 


\section{INTRODUCTION}

The herbicide glyphosate [ $N$-(phosphonomethyl) glycine] is commonly recommended to control troublesome weeds. This herbicide acts by inhibiting the enzyme 5-enolpyruvylshikimate-3-phosphate synthase (EPSPS), thereby causing rapid and high levels of shikimic acid to accumulate in affected plant tissues (Duke et al., 2003). Measurement of shikimic acid accumulation in response to glyphosate inhibition is a rapid and accurate way to quantify and predict glyphosate-induced damage in sensitive plants (Harring et al., 1998; Pline et al., 2002; Henry et al., 2007).

Weeds are rapidly developing resistance to glyphosate (Nandula et al., 2005; Powles $\&$ Preston, 2006). Thus, having a means of quickly identifying and characterizing glyphosate-resistant weed biotypes is important to mitigate their spread and to facilitate their effective management (Singh \& Shaner, 1998). Rapid and easy bioassays based on shikimate detection with excised leaf tissue were devised to differentiate resistant from susceptible maize, cotton, soybean, canola and biotypes of horseweed (Koger et al., 2005; Shaner et. al., 2005). Furthermore, determination of whether non-target plant damage is due to glyphosate drift, a growing problem with glyphosate-resistant crops (Cerdeira \& Duke, 2006) is increasingly important. Shikimic acid accumulation is a highly specific and sensitive chemical marker for plants exposed to glyphosate application (Henry et al., 2007; Anderson et al., 2001). Dramatic increases in glyphosate accumulation occur even in plants treated with low doses of glyphosate that do not cause phytotoxicity (Velini et al., 2008).

Furthermore, there is great interest in plants with high endogenous levels of shikimate, as it is the precursor to the antiflu drug, oseltamivir $\left(\right.$ Tamiflu $\left.^{\circledR}\right)$ (Enserink, 2006). At present, a significant fraction of shikimate for this purpose comes from star anise (Illicium verum), but this natural source is being depleted, and other botanical sources are being explored (Li et al., 2007). A fast, simple method could be very useful in large scale screening of plant species for this important compound.
Methods for the determination of shikimic acid include high performance liquid chromatography (HPLC) with UV detection (Harring et al., 1998), GC-MS (Duke et al., 2008) and spectrophotometry (Pline et al., 2002). Current extraction procedures require long extraction times and the use of high amounts of reagents such as methanol, ethanol, acetone, $\mathrm{HCl}$, and sulfuric acid (Harring et al., 1998; Anderson et al., 2001; Jaroszynska, 2003; Mueller et al., 2003; Li et al., 2007). More efficient extraction methodologies would give rise to less solvent waste. Microwave-assisted extraction (MWAE) has been investigated since 1986 because smaller amounts of matrix and solvents are required, and extraction is rapid (Andrea et al., 2001). This work investigates the feasibility of MWAE application in determining endogenous levels of shikimic acid in plants.

\section{MATERIALS AND METHODS}

\section{Plant material}

$B$. decumbens plants were grown in the field at the Biological Institute of Campinas, Brazil. The plants were cut close to the ground and then grown up to $30 \mathrm{~cm}$ of height, at which time they were treated with glyphosate. They were sprayed at a temperature average of $29^{\circ} \mathrm{C}$, a relative humidity of $60 \%$, and at the pre-flowering stage of full grown plants, using a $\mathrm{CO}_{2}$ sprayer with a Teejet ${ }^{\circledR}$ nozzle 110.01 at a pressure of $24.610^{3} \mathrm{~kg} \mathrm{~m}^{-2}$. A commercial formulation of glyphosate (isopropyl amine salt formulated at $360 \mathrm{~g} \mathrm{~L}^{-1}$ of a.e.) was used.

To further determine the endogenous shikimic acid in other Poacea species, plants of Brachiaria spp., including $B$. decumbens and B. ruziziensis (BRARU), B. brizantha (BRABR), $B$. dictyoneura (BRADT) and sugarcane (Saccharum officinarum, cv. RB855113) were grown in a greenhouse without glyphosate application. At 30 and 75 days after planting (DAP), the plant shoots were harvested, and the endogenous shikimic acid content was extracted and determined as described below.

To measure the shikimic acid levels in soybean (Glycine max, cv. Valiosa seeds were germinated in paper towel, transferred to 
plastic pots in a growth chamber at $25{ }^{\circ} \mathrm{C}$ for seven days until plants reached the $\mathrm{VE}$ growth stage and then placed into $50 \mathrm{~mL}$ Falcon centrifuge plastic tubes containing $30 \mathrm{~mL}$ of distilled water and kept in growth chamber at $25{ }^{\circ} \mathrm{C}$ for 7 days with constant light for adjustment. When the plants reached V1 stage (first trifoliolate), they were transferred to tubes with the following treatments: a) glyphosate (technical grade) at 10,20 and $30 \mathrm{mM}$; b) AMPA (Sigma-Aldrich, analytical) at 10,20 and $30 \mathrm{mM}$, and control with distilled water and kept in light for $24 \mathrm{~h}$ for incubation. After this period, leaves and roots were excised and dried at $60{ }^{\circ} \mathrm{C}$ for $16 \mathrm{~h}$ for before extraction. The experimental design used was CRD with ANOVA separation with $t$ (p d" 0,05). Shikimic acid content was extracted and determined as described below.

\section{Extraction method}

Whole leaves were placed in an open container and dried at ca. $60^{\circ} \mathrm{C}$ overnight $(16 \mathrm{~h})$. Samples were ground with a grinder at 25,000 rpm (IKA A11 Basic) placed in a PVC jar, and stored at $<-10{ }^{\circ} \mathrm{C}$. A dry ground sample of $1,200 \mathrm{mg}$ was taken and three sub-samples of $400 \mathrm{mg}$ each was spiked with 250,500 , and $1,000 \mu \mathrm{L}$ of aqueous solution of shikimic acid at $1,200 \mu \mathrm{g} \mathrm{mL}^{-1}$ (300; 600; and 1,200 $\mu \mathrm{g}$ added to each $400 \mathrm{mg}$ DW of plant material of each sub-sample). Fortified samples with 750,1500 , and $3,000 \mu \mathrm{g}$ of shikimate per gram of dry weight were prepared in triplicate. Then, $10 \mathrm{~mL}$ of distilled water acidified to $\mathrm{pH} 2.0$ with concentrated phosphoric acid was added to plastic tubes (50 mL capacity) containing the samples and the suspensions were equilibrated by shaking for $30 \mathrm{~min}$ at a minimum of $32 \mathrm{rpm}$ before extraction. The parameter settings in the microwave system (Panasonic Model NN-S62 B) were $10 \mathrm{sec}$ and $100 \mathrm{~W}$. The extraction was performed at $\left.49.8{ }^{\circ} \mathrm{C} \pm 2.8{ }^{\circ} \mathrm{C}\right)$. Each sample was placed in the center of the microwave turntable. Once the extraction was completed, the sample was cooled for 5 min before opening. After extraction, vessel contents were filtered through Whatman no. 1 filter paper and a $0,22 \mu \mathrm{m}$ membrane filter (Millex-GV, Millipore) into a vial for chromatographic analysis.

\section{HPLC quantification}

The concentration of shikimic acid was determined using a Shimadzu LC 2010 chromatograph equipped with a Class VP 6.0 software, autoinjector, and photodiode array detector using a detection wavelength of $212 \mathrm{~nm}$. A Phenomenex Gemini C18 $110 \mathrm{~A}^{\circ}$ column ( $250 \mathrm{~mm} \times 4,0 \mathrm{~mm} ; 5 \mu \mathrm{m}$ particle size) was used with an injection volume of $20 \mu \mathrm{L}$. The isocratic system used 95:5 deionized water at $\mathrm{pH}$ 3.0: methanol and a flow rate of $1.0 \mathrm{~mL} \mathrm{~min}{ }^{-1}$. The total running time was $10 \mathrm{~min}$, with shikimate retention time at $5.1 \mathrm{~min}$.

A seven point calibration curve with shikimate concentrations ranging from 2.04 to $407.2 \mu \mathrm{g} \mathrm{mL}^{-1}$ was used to quantify shikimate levels. The relationship between amount of shikimate and the peak area was linear with a correlation coefficient of 0.999 . With this method, the detection limit for shikimate was $0.395 \mu \mathrm{g} \mathrm{mL} \mathrm{m}^{-1}$.

\section{RESULTS AND DISCUSSION}

The HPLC analytical method provided a clearly distinct chromatographic peak without interference (Figure 1). The shikimic acid absorbance spectrum is shown in the inset of Figure 1. The UV spectra of both shoulders of the shikimic acid peak maximum were essentially identical and the similarity index of the spectra in a peak equals to 0.9999 to confirm the purity of the shikimic acid peak. This purity was also demonstrated by the linear relationship between the signals obtained at 202, 207, 212, 217 and $222 \mathrm{~nm}$ (data not shown), showing the consistency of the peak and specificity of the method, although the use of DAD alone is by no means conclusive in establishing peak purity (Krull et al., 1997).

Shikimic acid eluted at $4.8 \mathrm{~min}$, with a total analysis time of $10 \mathrm{~min}$. The reversedphase HPLC method was isocratic, simplifying the procedure. The mobile phase $\mathrm{pH}$ was a variable that had a profound effect on retention time of shikimic acid. At pH 3 more than 95\% of the shikimic acid was in the non-ionized form, and consequently less polar, so it will be more strongly retained. According to 


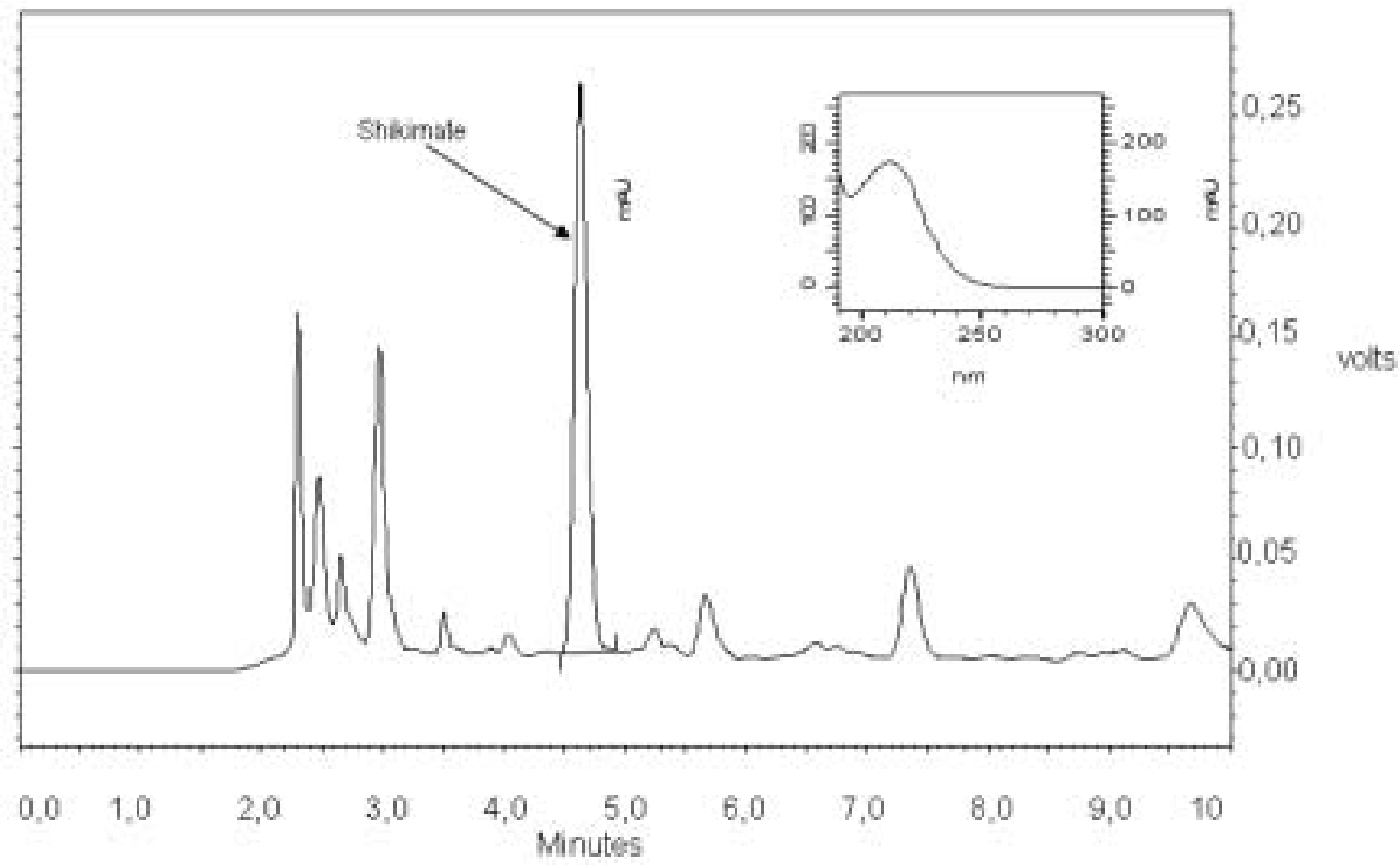

Figure 1 - Chromatogram at $212 \mathrm{~nm}$ of shikimic acid in B. decumbens samples. Inset is the absorption spectrum of the shikimate peak.

Dolan (2005), ionic compounds often are retained poorly under reversed-phase conditions. The column has shown no restrictions regarding $\mathrm{pH}$, allowing its use at $\mathrm{pH}$ levels below 3. For typical silica-based reversed-phase columns, hydrolysis of the bonded phase takes place at $\mathrm{pH}<2$, and the silica dissolves.

In Figure 2, the individual points represent the corresponding average recoveries at the different fortification levels based on $1,199 \mu \mathrm{g} \mathrm{g}^{-1}$ endogenous shikimate plus additions of $750,1,500$ and $3,000 \mu \mathrm{g} \mathrm{g}^{-1}$ of shikimic acid, while the line represents a simple linear regression of spiked vs. recovery values. Over the fortification range used, there was a nearly linear level of recovery of added shikimate. There seems to be a slight upward trend in recovery as a function of fortification level. The equation of the fitted model is $y=0.9998 x+83.86$. Since the P-value in the ANOVA is < 0.001 there is a statistically significant linear relationship between the recoveries and predicted values at the $99.97 \%$ confidence level, with a correlation coefficient of 0.9998 , indicating a strong relationship between recovery values and fortification levels of shikimate.

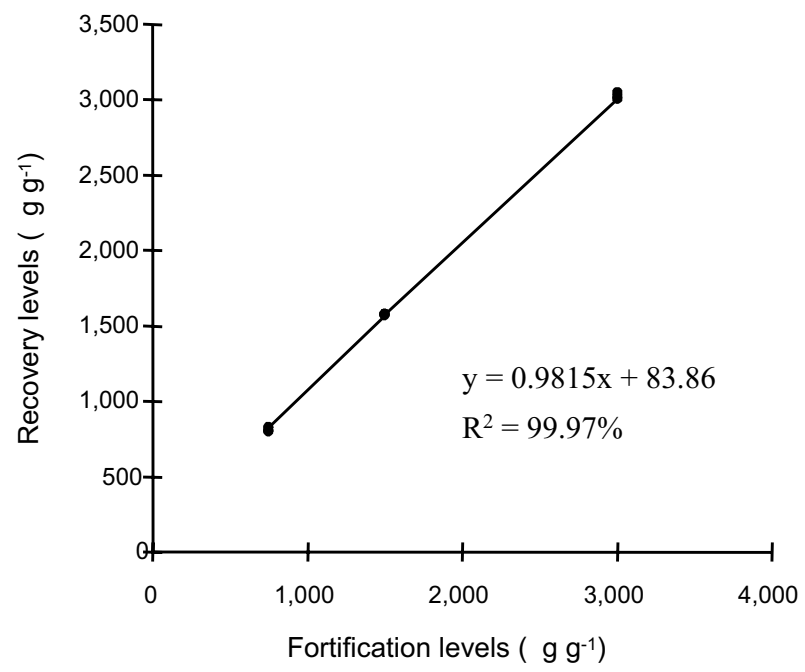

Figure 2 - Analytical recoveries for additions of 750, 1,500, and $3,000 \mu \mathrm{g} \mathrm{g}^{-1}$ of shikimic acid. Endogenous levels of shikimate were subtracted from recovery values. 
Our shikimic acid analytical method performed well in the analysis of $B$. decumbens samples, as demonstrated with the results with endogenous shikimic acid and spiked samples. The average background level of shikimic acid in untreated $B$. decumbens was $1,199 \pm 12 \mu \mathrm{g} \mathrm{g}^{-1}$ dry weight, as determined by multiple extractions of unspiked samples. The average recoveries of shikimic acid from freshly fortified plant material were as follows: a) $91.3 \pm 0.7 \%$ at $750 \mu \mathrm{g} \mathrm{g}^{-1}$ level of fortification, b) $94.3 \pm 0.2 \%$ at $1,500 \mathrm{mg} \mathrm{g}^{-1}$ leve1 of fortification and c) $95.1 \pm 0.5 \%$ at 3,000 $\mu \mathrm{g} \mathrm{g}^{-1}$ level of fortification. The analyses were performed on a dry-weight basis to eliminate variability in moisture of the plants.

Our data are in agreement with previous studies performed using an acid or water extraction, followed by HPLC analysis. Singh $\&$ Shaner (1998) and Mueller et al. (2003) reported recoveries higher than $80 \%$ of spiked shikimic acid in crude extracts of soybean, maize and horseweed. Recoveries of $100 \%$ of shikimic acid in spiked samples of cotton, and $85 \%$ to $104 \%$ in fortified wheat tissue were also reported by Pline et al. (2002) and Anderson et al. (2001), respectively.

Using the above method, we determined the level of shikimate in $B$. decumbens plants treated with the herbicide glyphosate. In this experiment, the control levels of shikimate were somewhat higher than the plants used in the spiking experiment (Figure 2), probably due to differences in growth conditions or plant age. We were surprised to find a consistent, small, but significant reduction in the shikimate level at both three and seven days after treatment at the lowest treatment rate (Figure 3). The effect of glyphosate on shikimate accumulation became greater after 7 days of treatment. The results here are very similar to those of Lydon \& Duke (2003) with ryegrass treated with glyphosate. The control concentrations of shikimate and the responses to glyphosate with time ( 3 and 6 days in this case) were very similar.

The method was used to determine the shikimic acid content at two growth stages of sugarcane and several Brachiaria species (Figure 4). The tissues of sugarcane, BRADC, and BRARU contained more shikimic acid at 75 days after planting (DAP) than at 30 DAP. At this time BRADC contained the highest level of shikimic acid, followed by BRARU, BRADT, BRABZ, and sugarcane. The differences in the endogenous levels of shikimate in untreated BRADC from the two experiments (Figures 3 and 4) are probably due to the environmental conditions (field vs. greenhouse) and the time of the year.

We used the method to measure shikimate levels in roots and shoots of glyphosatesusceptible soybean treated with different concentrations of glyphosate and AMPA (Figures 5 and 6). AMPA, a common degradation product of glyphosate (Duke et al., 2008) had no statistically significant effect on shikimate levels in either tissue type. This is to be expected as AMPA has no effect on the shikimate pathway (Amrhein et al., 1980). Glyphosate greatly increased shikimate levels in all treatments and tissues, with increasing

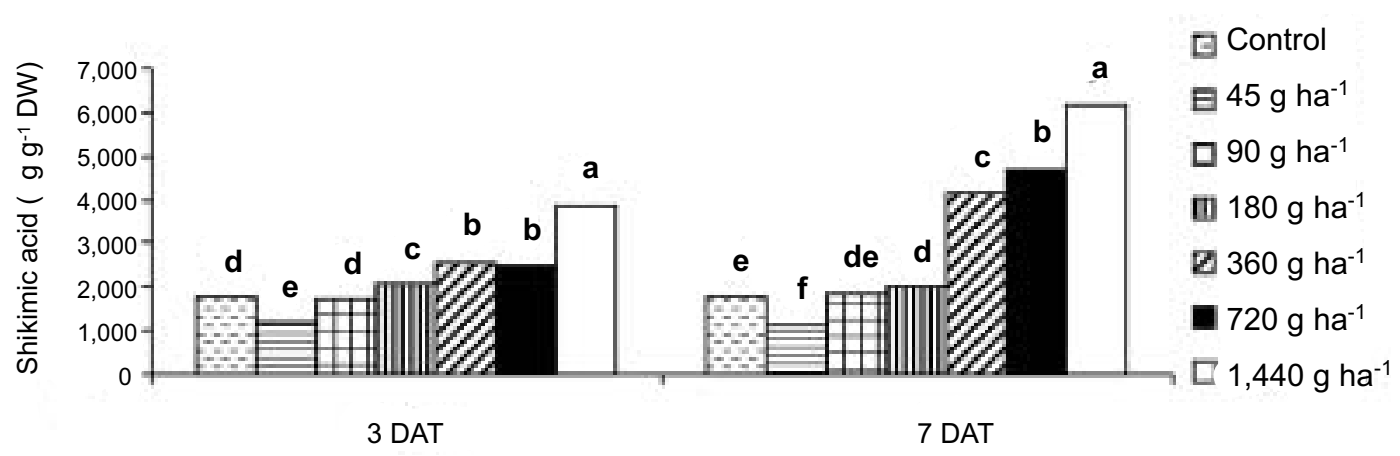

Figure 3 - Effect of glyphosate rates (g ha-1 e.a.) on shikimic acid on Brachiaria decumbens (DAT = Days after treatment). Means followed by the same letter within each time after treatment do not differ significantly, according to the Tukey test $(0.5 \%)$. 


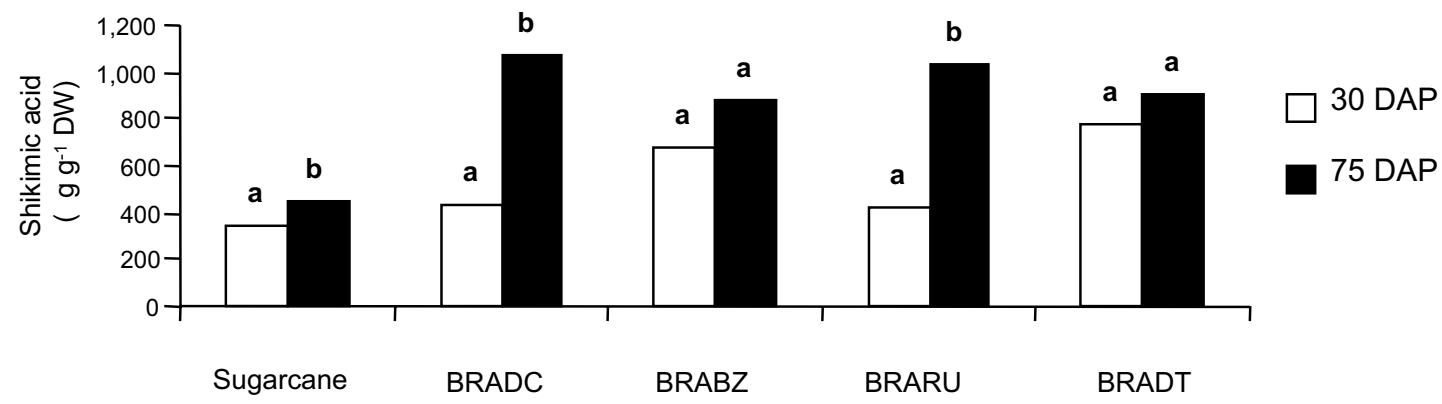

Figure 4 - Shikimic acid content on Brachiaria spp. and sugarcane at 30 and 75 DAP. Means followed by the same letter for each species do not differ significantly within each time according to the $t$ test $(0.5 \%)$.

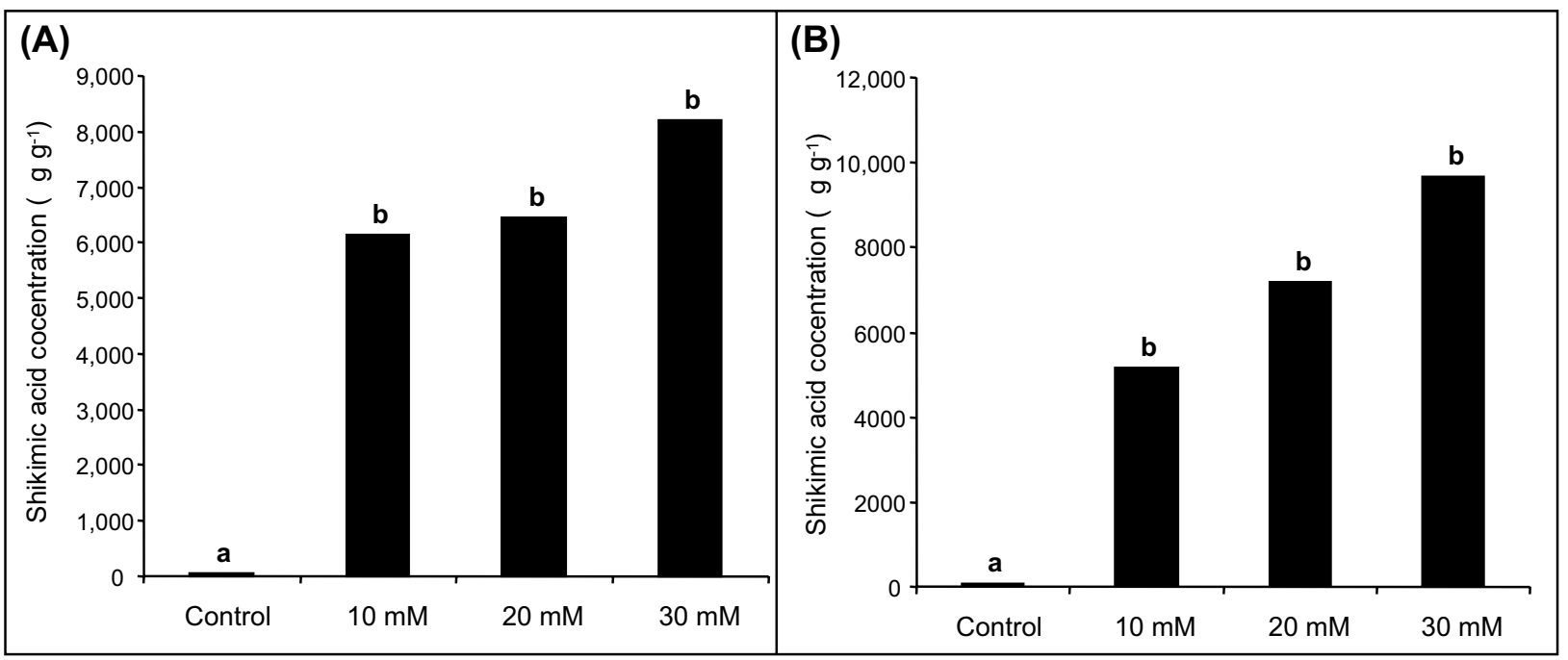

Figure 5 - Shikimate content of soybean shoot (A) and root (B) tissues treated with increasing concentrations of glyphosate for 24 h. Means followed by the same letter do not differ statistically at $5 \%$ of probability.

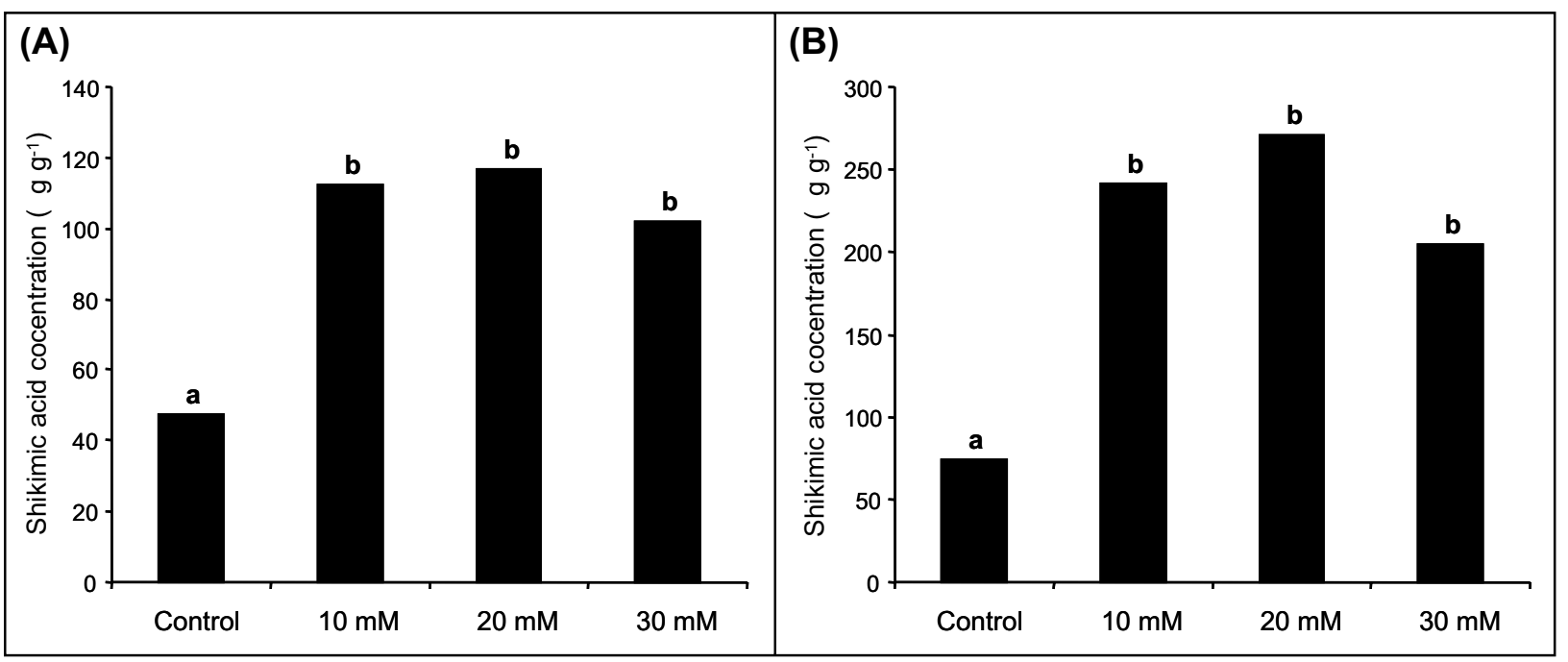

Figure 6 - Shikimate content of soybean shoot (A) and root (B) tissues treated with increasing concentrations of AMPA. Means followed by the same letter do not differ statistically at $5 \%$ of probability. 
effects with increasing concentrations, reaching about $1 \%$ of the weight (DW) of the tissues.

There was a wide range in shikimate content of untreated/treated tissues between species, ranging from less than $100 \mu \mathrm{g} \mathrm{g}^{-1}$ in soybean (Figure 6) to levels more than ten fold higher in Brachiaria species (Figures 3 and 4). These results are consistent with the range of endogenous shikimate levels found in a study of grass and broadleaf species (Reddy et al., 2008). In this study, levels ranged from about $2 \mu \mathrm{g} \mathrm{g}^{-1}$ in velvetleaf (Abutilon theophrasti) to approximately $900 \mu \mathrm{g} \mathrm{g}^{-1}$ in Italian ryegrass (Lolium perenne). Our method could be very useful in large scale screening of plant species for shikimic acid in the search for improved sources for the manufacture of oseltamivir $\left(\right.$ Tamiflu $\left.{ }^{\circledR}\right)$.

The extraction technique developed in this paper uses a simple water MWAE extraction. In contrast, other shikimic acid methods use various reagents such as sulfuric acid (Harring et al., 1998), HCl (Mueller et al., 2003) and alcohols (Anderson et al., 2001; Jaroszynska 2003). Our method provides close to $100 \%$ extraction efficiency and a high level of sensitivity without interference with other compounds. In this paper, we have shown that it is applicable to a variety of plant tissues grown under a variety of conditions.

\section{LITERATURE CITED}

AMRHEIN, N. et al. The site of the inhibition of the shikimate pathway by glyphosate. II. Interference of glyphosate with chorismate formation in vivo and in vitro. Plant Physiol., v. 66, p. 830-834, 1980.

ANDERSON, K. A.; COBB, W. T.; LOPER, B. R. Analytical method for determination of shikimic acid Shikimic acid proportional to glyphosate application rates. Comm. Soil Sci. Plant Anal., v. 32, n. 17-18, p. 2831-2840, 2001

ANDREA, M. M.; PAPINI, S.; NAKAGAWA, L. E. Optimizing microwave-assisted solvent extraction (MASE) of pesticides from soil. J. Environ. Sci. Health, B., v. 36, n. 1, p. $87-94,2001$

CERDEIRA, A. L.; DUKE, S.O. The current status and environmental impacts of glyphosate-resistant crops: A review. J. Environ. Qual., v. 35, n. 5, p. 1633-1658, 2006.
DOLAN, J. W. What mobile phase conditions will give good results? LC/GC North America. July, 2005.

DUKE, S. O.; BAERSON, S. R.; RIMANDO, A. M. Herbicides: Glyphosate. In: PLIMMER, J. R.; GAMMON, D. W.; RAGSDALE, N. N. (Eds.) Encyclopedia of Agrochemicals. New York: John Wiley \& Sons, 2003. Available in: <http://www.mrw.interscience.wiley.com/eoa/ articles/agr119/frame.html> Access in: 26 Aug. 2008.

DUKE, S.O. et al. Isoflavone, glyphosate, and aminomethylphosphonic acid levels in seeds of glyphosatetreated, glyphosate-resistant soybean. J. Agric. Food Chem. v. 51, n. 1, p. $340-344,2008$

ENSERINK, M. Oseltmivir becomes plentiful - but still not cheap. Science, v. 312, p. 382-383, 2006.

HARRING, T.; STREIBIG, J. C.; HUSTED, S. Accumulation of shikimic acid: A technique for screening glyphosate efficacy. J. Agric. Food Chem., v. 46, n. 10. p. 4406-4412, 1998

HENRY, W. B.; SHANER, D. L.; WEST, M. S. Shikimate accumulation in sunflower, wheat, and proso millet after glyphosate application. Weed Sci., v. 55, n. 1, p. 1-5, 2007.

JAROSZYNSKA, J. Isolation of free phenolic compounds from arboreal leaves by use of the Florisil/ $\mathrm{C}_{18}$ system. Anal. Bioanal. Chem., v. 377, n. 4, p. 702-708, 2003

KOGER, C. H. et al. Assessment of two nondestructive assays for detecting glyphosate resistance in horseweed (Conyza canadensis). Weed Sci., v. 53, n. 4, p. 559-566, 2005.

KRULL, I. S.; SZULC, M. E.; WU, S. L. Detection sensitivity and selectivity. In: SNYDER, L. R.; KIRKLAND, J. J.; GLAJCH, J. L. (Eds.) Practical HPLC method development. 2.ed. New York: John Wiley \& Sons, 1997. p. 59-99.

LI, S. Improved methods for producing shikimic acid and the use of sweetgum plant tissues in the production of shikimic acid. United States Patent Application 20070149805, June 28,2007

LYDON, J.; DUKE, S. O. Glyphosate induction of elevated levels of hydroxybenzoic acids in higher plants. J. Agric. Food Chem., v. 36, n. 4, p. 813-818, 2003.

MUELLER, T. C. Shikimate accumulates in both glyphosatesensitive and glyphosate-resistant horseweed (Conyza canadensis L. Cronq.) J. Agric. Food Chem., v. 51, n. 3, p. 680-684, 2003.

NANDULA, V. K. et al. Glyphosate-resistant weeds: current status and future outlook. Outlooks Pest Manag., v. 16, n. 4, p. 183-187, 2005. 
PLINE, W. A. et al. Tolerance and accumulation of shikimic acid in response to glyphosate applications in glyphosateresistant and nonglyphosate-resistant cotton (Gossypium hirsutum L.). J. Agric. Food Chem., v. 50, n. 3, p. 506-512, 2002.

POWLES, S. B.; PRESTON, C. Evolved glyphosate resistance in plants: Biochemical and genetic basis of resistance. Weed Technol., v. 20, n. 2, p. 282-289, 2006

REDDY, K.N. et al. Aminomethylphosphonic acid accumulation in plant species treated with glyphosate. $\mathbf{J}$. Agric. Food Chem., v. 56, p. 2125-2130, 2008
SHANER, D. L. et al. A rapid in vivo shikimate accumulation assay with excised leaf discs. Weed Sci., v. 53, n. 6, p. $769-774,2005$.

SINGH, B. K.; SHANER, D. L. Rapid determination of glyphosate injury to plants and identification of glyphosateresistant plants. Weed Technol., v. 12, n. 3, p. 527-530, 1998.

VELINI, E. D. et al. Glyphosate applied at low doses can stimulate plant growth. Pest Manag. Sci., v. 64, n. 4, p. 489-496, 2008. 